\title{
Karinis konfliktas informacijos amžiuje ir Lietuvos pasirengimas
}

\begin{abstract}
Informacinè revoliucija keičia tarptautinę sistemą ir saugumo aplinką, kurioje mes gyvename. Valstybė praranda galios monopoli globalioje informacinejje erdvejje. Tačiau tos pačios technologijos tampa ir naujo tipo kariniu konfliktu irankiais. Griūna Vakaru civilizacijos suvokimas apie karinį konfliktą: anksčiau remtasi Carl von Clausewitz modeliu, kai vadovai iškelia politinius tikslus ir kontroliuoja karius, kariai tiesiogiai kariauja ir yra teisèti smurto taikiniai, civiliai nedalyvauja konflikte, bet remia savo vadovus per mokesčių sistemą bei palaiko jų iškeltus politinius tikslus. Informacijos amžiaus konfliktas - tai tam tikra prasme ikivestfalinis konfliktas, kai nusikaltimai prieš civilius ir valstybès vidaus tvarka buvo norma.

Kyla klausimas - kaip valstybė gali užtikrinti savo piliečių saugumą? Didžiosios valstybės atsakymą bando rasti sudarant informacinių operacijų strategijas ir programas. Didelis dėmesys čia skiriamas valstybès viešajai informacijai konflikto metu bei informacijos saugumui. Pastarojoje srityje Lietuva jau žengè pirmuosius žingsnius, tačiau viešosios informacijos principų - ne tik karinio konflikto, bet ir taikos metu - mūsų valstybei derètų pasimokyti.
\end{abstract}

\section{Ivadas}

Kariniai konfliktai - tai neatsiejami tarptautinès sistemos raidos, jos kaitos elementai. Dẻl tarpvalstybinių karų kisdavo teritorijų priklausomybè, įitvirtindavo naujos tarptautinių santykių normos: laimėtojams užtikrinamas palankus status$q u o$, atsirasdavo naujų tarptautinių organizacijų, tarptautinių režimų. Tačiau toks santykis visada buvo abipusis: tarptautineje sistemoje vykstantys procesai lemdavo karinio konflikto pobūdị, potencialius jo dalyvius, naudojamas priemones.

Vienas esminiu globalių procesų, kuris prasidẻjo gerokai anksčiau, nei baigèsi Šaltasis karas, yra informacinè revoliucija. Ji paveikẻ kiekvieną žmogų, kasdienę jo veiklą, ekonomines, visuomenines ar kitokias institucijas ir, svarbiausia, kiekvieną valstybę, jos vaidmenį tarptautinėje arenoje. Teigiama, kad po industrinès revoliucijos arba po branduolinio amžiaus, kurie buvo praeito amžiaus varomosios jẻgos, prasideda informacijos amžius. Tarptautiniuose santykiuose formuojasi globali informacinè erdvè, kur komunikacijos priemonès ir informacinès technologijos panaikina laiko ir erdvės ribas. Taigi keičiasi tarptautinè sistema, formuojasi nauja saugumo aplinka, drauge keičiasi ir karinių konfliktu pobūdis.

XX amžiaus pabaigoje ypač sumažejo informacijos surinkimo, skleidimo bei efektyvaus naudojimo kaštai. Tai ịvyko dèl sparčios informacinių technologijų rai-

"Nerijus Maliukevičius - Vilniaus universiteto Tarptautinių santykių ir politikos mokslų instituto doktorantas. Adresas: Vokiečių 10, 01130 Vilnius, tel. 8-5-2514130,

e-paštas: n.maliukevicius@vilsat.net. 
dos. Todèl nenuostabu, kad šiuo metu daugelis valstybių, îskaitant ir Lietuvą, plètoja informacinès visuomenès, žinių visuomenès, elektroninės vyriausybės ir pan. programas, nes savo gerovę sieja su efektyviu informacijos panaudojimu.

Teigiama, kad ,informacija - tai ne tik gamybos, bet ir griovimo pagrindas“" . Informacinè revoliucija paveike konfliktą, kuris gali vykti ịvairiais lygiais. Rusijoje dažnai aptariami informaciniai karai tarp oligarchų ar politikų, o tokios valstybès, kaip JAV, Kanada, Rusija ar Kinija, vysto informacinių operacijų programas ar strategijas, su kuriomis sieja savo valstybès saugumą arba dalyvavimą ateities kariniuose konfliktuose.

Šiame straipsnyje siekiama pažvelgti, kokią įtaką informacinè revoliucija padarè karinio konflikto pobūdžiui, kaip ateities konfliktai suvokiami JAV ir NATO, kokiomis priemonèmis šios organizacijos užtikrins savo saugumą. Siekiama pažvelgti, ko Lietuva galètų pasimokyti iš šių karinių galios centrų.

Naują požiūrị į karinị konfliktą apibendrina informacinių operacijų samprata* ${ }^{*}$ kuri straipsnyje bus apžvelgta išsamiau. Lietuva netrukus taps NATO nare, mūsų šalis konfliktų Afganistane ir Irake metu buvo suteikusi galimybę JAV ir kitoms NATO sajungininkėms prireikus naudotis Lietuvos oro erdve ir oro uostais. Be to, Lietuva pasiuntė savo karininką į JAV karinių pajëgų vadavietę (CENTCOM), o šalies specialiujų pajègų kariai, karo medikai, krovinių gabenimo specialistai dalyvauja realiose karinèse operacijose. Nepaisant to, susidaro įspūdis, kad Lietuvos politikai, karo ekspertai miglotai suvokia informacinį karą, informacines operacijas bei informacinį saugumą, kaip šie reiškiniai lemia priimamus politinius ar karinius sprendimus. Matyt, daroma prielaida, kad informacinès operacijos ar gynyba nuo jų - tai didžiujų bei turtingujjų valstybiu prerogatyva. Tačiau tokia prielaida yra klaidinga ir tai ịrodo Austrijos pavyzdys, kuris bus pristatytas straipsnyje.

Taigi šio straipsnio tikslas nėra bandyti įrodyti, kad Lietuva turètų kurti analogišką JAV informacinių operacijų strategiją ir tam mesti didžiulius finansinius resursus,- tai netikslinga, nes tapusi NATO nare ji perims šios gynybinès sajungos analogiškų operacijų patirtị ir standartus. Priešingai, tikslas - atskleisti, ką šioje sferoje yra pasiekusios JAV, NATO ir ką Lietuva turètų perimti spręsdama savo valstybės administravimo bei politikos klausimus. Informacinių technologijų saugumo užtikrinimo sferoje mūsų valstybẻ jau žengia pirmuosius žingsnius - patvirtinta Informacinių technologijų saugos valstybinè strategija bei jos įgyvendinimo priemonių planas. Tuo tarpu dabartinė valstybės viešosios informacijos politika yra nekoordinuota - potencialaus karinio konflikto metu mūsų valstybè susidurtų su ypatingais sunkumais. Todèl būtina pasinaudoti NATO patirtimi šioje sferoje.

\section{Informacinè revoliucija ir tarptautinè sistema}

Daugelis autorių, bandančiu apibendrinti tarptautinès sistemos vaizdą po Šaltojo karo, daro išlygą, kad dešimtmetis - tai per mažas laiko tarpas, norint konstatuoti, kad jau nusistovejo vienokia ar kitokia šios sistemos būsena. Populiaru pateikti

${ }^{1}$ Baylis J., Smith S., eds., The Globalization of World Politics, Oxford University Press, 1997, p. 554. " Kartais vartojamas informacinio karo terminas, tačiau oficialiuose JAV ir NATO dokumentuose vartojama informacinių operacijų sąvoka. 
keletą scenarijų: pvz., Huntington, Fukujamos, kapitalistinės sistemos pergalès, Pax Amerikana ir pan. scenarijai. Ian Clark manymu, kol tarptautinių santykių disciplinoje ir pačioje tarptautinèje sistemoje vyrauja chaosas, šị laikotarpị teisingiausia būtų apibūdinti kaip „,naujos istorinès epochos pradžią, kurios dominuojantis tarptautinių santykių faktorius yra fragmentacija“2 . Autorius tokią išvadą prieina dèl dviejų priežasčių: visų pirma kartu su Šaltuoju karu baigèsi sisteminès priešpriešos tarp kapitalistinio ir komunistinio polių laikotarpis, antra, ši sisteminė priešprieša neutralizavo arba vieno iš poliu naudai pajungè visas kitas etnines, nacionalines, religines aspiracijas. Žlugus bipolei sistemai, visos šios jëgos tapo nebekontroliuojamos. Todèl Ian Clark teigia, kad pagrindinis tarptautinių santykių ekspertų uždavinys šiuo metu yra nustatyti naujas konflikto ašis, o jų, skirtingai nei Šaltojo karo metu, gali būti keletas ${ }^{3}$. Tokiame kontekste ypač svarbu išsiaiškinti, koks yra modernios valstybės vaidmuo garantuojant savo piliečių saugumą.

Daugelis autorių pabrěžia, kad nyksta valstybės suvereniteto reikšmè tarptautiniuose santykiuose, t. y. daroma prielaida, kad valstybe praranda galios monopoli. Didžia dalimi tai sąlygojo informacinè revoliucija - valstybė prarado monopoli i informaciją. Ši procesą pradèjo M. Thatcher ir R. Reagan telekomunikacijų revoliucija $^{4}$. Taigi prasidejjo globalus telekomunikacijų sektoriaus dereguliacijos procesas", dèl to tarptautinèje arenoje išaugo telekomunikacijų korporacijų reikšmè. John Baylis ir Steve Smith teigia, kad informacinè revoliucija tarptautinès sistemos dalyviams turejjo nemažą itaką. ${ }^{5}$ Pirma, vis daugiau informacijos yra prieinama valstybèms ir kitiems tarptautinių santykių dalyviams, tačiau tai turi teigiamą poveikị tik tada, jei sugebama šią informaciją efektyviai apdoroti ir panaudoti, priešingu atveju iškyla informacijos pertekliaus problema. Antra, globalūs informacijos kanalai leidžia decentralizuoti valdymą, tuo naudojasi transnacionalinès korporacijos, tarptautinès organizacijos, net teroristinès grupuotės, tuo tarpu valstybès valdymas yra paremtas centralizuotu sprendimų priëmimo mechanizmu, todèl šioje srityje valstybè susiduria su rimtais sunkumais. Trečia, nebèra informacijos kontrolès monopolio, todèl išauga žiniasklaidos, ypač pasaulinių televizijos kompanijų, vaidmuo. Ketvirta, informacinè revoliucija pasireiškia globaliu skaidrumu, t. y. problemos, kurios anksčiau buvo laikomos valstybių vidaus reikalu, tampa globaliomis problemomis, ir tai tik pagilina valstybès suvereniteto erozija. M. E. Olsen ir M. N. Marger teigia, kad žiniasklaida, kuri yra pagrindinè informacijos formuotoja ir skleideja, dẻl informacinès revoliucijos tapo viena iš pagrindinių galios institucijų tarptautineje sistemoje ${ }^{6}$.

Tačiau reikia atsižvelgti ir ị tai, kad informacinè revoliucija valstybėms suteikia ir tam tikrų galimybių. Globaliame pasaulyje valstybė gali įtvirtinti savo galią ne vien kariniu ar ekonominiu potencialu, bet ir komunikacija grindžiama kultūros

${ }^{2}$ Clark I., Globalization and Fragmentation: International Relations in The Twentieth Century, Oxford University Press, 1997, p. 172.

${ }^{3}$ Ten pat, p. 174.

${ }^{4}$ John Baylis, Steve Smith., eds., (note 1) p. 542.

" 1981 m. priimtas Britanijos telekomunikacijų įstatymas, 1984 m. suskaidyta JAV telekomunikacijų monopolistė AT\&T.

5 John Baylis, Steve Smith, eds., (note 1) p. 549.

${ }^{6}$ Olsen M. E., Marger M. N., eds., Power in Modern Societies, Westview Press, 1993, p. 238. 
sklaida. H. H. Frederick valstybes, vykdančias tokią politiką ir taip išnaudojančias savo galią, vadina hegemonais ${ }^{7}$. Tai labai suprastintas sąvokos vartojimas, tačiau šiuo atveju ji puikiai apibūdina JAV politiką po Šaltojo karo.

\section{Informacijos revoliucija ir konfliktas}

Taigi valstybė, siekdama piliečių saugumo, turi prisitaikyti prie globalios informacinès aplinkos ir drauge keistis. Visos modernios kariuomenès investuoja dideles lèšas ị komunikacijų ir informacinių technologijų sektorių. Kinta karo technologija ir strategija. Skirtingas strategijas JAV karo ekspertai palygina tokiomis schemomis:

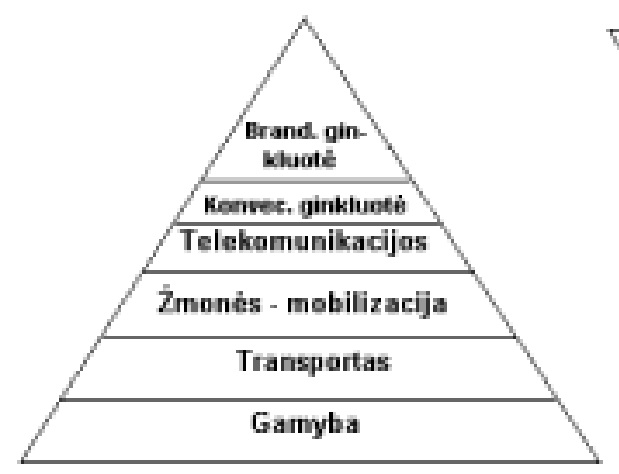

INDUSTRIJOS AMŽIUS

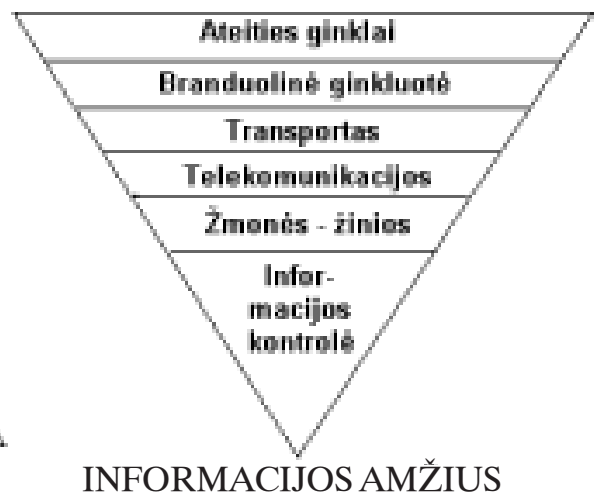

INFORMACIJOS AMŽIUS

1 schema. Industrijos ir informacijos amžių karo strategijų piramidès ${ }^{8}$

Globalioje informacinėje erdvejje vykstančių modernių karinių konfliktų metu lemiamą reikšmę turi informacijos kontrolè bei efektyvus ją lemiančių priemonių taikymas.

Dabar vykstantị paradigminị pokytị galima palyginti su tuo, kuris vyko po Vestfalijos sutarties. Prieš Trisdešimties metų karą nebuvo aiškaus skirtumo tarp karinès kampanijos ir masinio banditizmo. Richard Mansbach ir Edward Rhodes teigia, kad Vestfalijos sutartimi Europos valstybių lyderiai nusprendè apriboti karą, ir tai nulèmé ateities karinių konfliktų pobūdị ${ }^{9}$. Nuo to laiko pradèta skirti, kas yra „legitimus“ kariavimas - vykdomas profesionalių karių prieš kitus karius, siekiant konkrečių valstybių vadovų iškeltų politinių tikslų, ir kas yra „nelegitimus“ kariavimas - nusikaltimai prieš civilius ir valstybės vidaus tvarką. Taigi „,kariauja tam tikrai valdžiai (suvereniai valstybei) atsakinga individų grupe (profesionalūs kariai) ir remiamasi aiškiai apibrèžtomis taisyklèmis, ribojančiomis smurto naudojimą “10. Smur-

${ }^{7}$ Frederick H. H., Global Communication and International Relations, Belmont: Wadsworth Publishing Company, 1992, p. 205.

${ }^{8}$ Report of the Defence Science Board Task Force on Information Warefare - Defence. - Defense Science Board, 1996. http://cryptome.org/iwdmain.htm 06092003.

${ }^{9}$ Mansbach R., Rhodes E., eds., Global Politics in a Changing World, Boston: Houghton Mifflin, 2003, p. 35 .

${ }^{10}$ Ten pat, p. 35 . 
tas tapo dar viena politikos priemone, kurią galëjo naudoti Europos valstybių monarchai, kai kitomis priemonėmis nepavykdavo pasiekti norimų tikslų. Tokia kontroliuojamo smurto samprata tapo Prūsijos karininko Clausewitz teorijos apie karą pagrindu. Šio karininko teiginys apie karą kaip politiką, vykdomą kitomis priemonèmis, bei jo sukurta karo trikampio samprata suformavo Vakarų civilizacijos suvokimą apie karinị konfliktą. Tačiau dabar šis suvokimas sparčiai kinta ir panašu, kad grižtama prie ikivestfalinès karinio konflikto sampratos: nusikaltimai prieš civilius ir valstybès vidaus tvarką tampa norma.

Prielaidos pokyčiams atsirado daug anksčiau. Clausewitz teorijoje karo trikampio kampuose atsiduria šie trys veiksniai: vadovai iškelia politinius tikslus ir kontroliuoja karius, kariai tiesiogiai kariauja ir yra teisèti smurto taikiniai, civiliai nedalyvauja konflikte, bet remia savo vadovus mokesčiais bei palaiko jų iškeltus politinius tikslus. Šis karininkas suformulavo riboto, arba kontroliuojamo, karo sampratą. Tačiau I ir II Pasauliniai karai, Richard Mansbach ir Edward Rhodes manymu, pademonstravo, kaip karinės technologijos pokyčiai, galimybė mobilizuoti visos valstybès ekonomiką karo reikalams bei išplitęs nacionalizmas gali sugriauti ši teorinị trikampị ${ }^{11}$. Pasauliniai karai buvo totalūs, kur nebuvo daromas skirtumas tarp karių ir civilių, o valstybių vadovai labai sunkiai kontroliavo konflikto procesus. Šaltojo karo metu karine technologija buvo toliau vystoma, ir JAV, ir Sovietų Sajunga sukūrè branduolinį ginklą. Šaltajam karui pritaikius Clausewitz teoriją, galima teigti, kad karas tarp supervalstybių tapo neįmanomas, nes, vykdomas kitomis priemonemis, jis nebūtų racionalios politikos pavyzdys. Tačiau riboti kariniai konfliktai šiuo laikotarpiu vyko, pavyzdžiui, Vietname, Afganistane. Po Šaltojo karo karinè technologija toliau vystèsi neįtikètinais tempais, tačiau karinị konfliktą Persijos ịlankoje Lawrence Freedman ir Efraim Karsh dar priskiria ribotų karų tipui ${ }^{12}$, kuriems pritaikoma Clausewitz karo trikampio samprata: JAV vadovybè turejjo aišku politinį tikslą - išvyti Irako armiją iš Kuveito; šị ivvykdžius, Prezidento G. W. Bush administracija kito tikslo nuversti Sadamą Huseiną - nebekèlé; koalicijos vykdomi tiksliniai smūgiai gali būti Clausewitz akcentuojamo aiškaus karių ir civilių atskyrimo iliustracija; be to, ne tik JAV visuomene, bet ir tarptautinè bendruomenè palaikè koalicijos veiksmus ir buvo tuo trečiuoju ramsčiu.

\footnotetext{
${ }^{11}$ Ten pat, p. 35

${ }^{12}$ Ten pat, p. 49.
} 
Tačiau šis konfliktas jau vyko naujoje aplinkoje, kurią JAV, Kanados, NATO karo ekspertai vadina globalia informacine erdve:

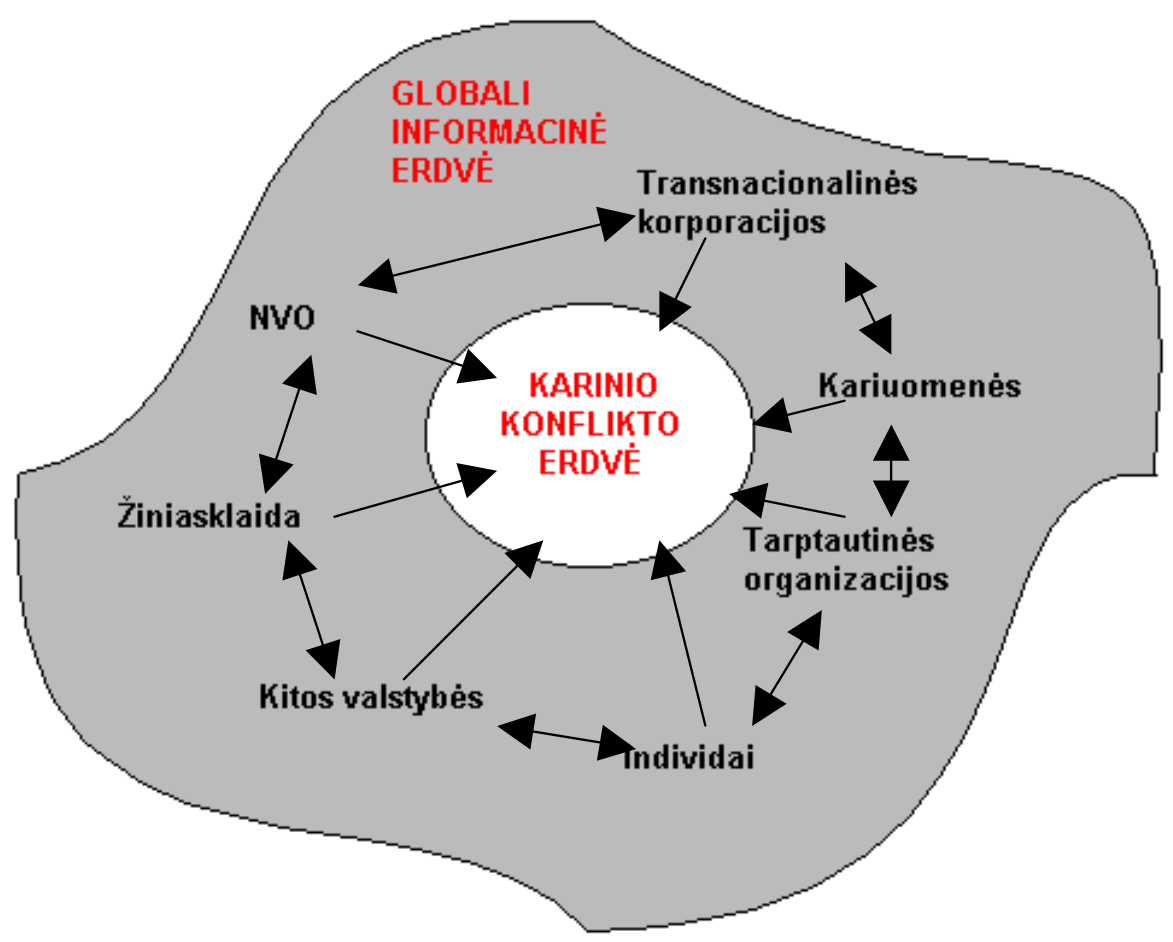

2 schema. Karinio konflikto vieta globalioje informacinèje erdvejje ${ }^{13}$

Globali informacinė erdvè - tai institucijos, organizacijos, sistemos, esančios už karinio konflikto ribų, tačiau galinčios daryti ịtaką pačiam konfliktui. Anksčiau šią erdvę išskirtinai kontroliavo valstybės, tačiau informacijos amžiuje reikšmingas gali būti kiekvienas tarptautinių santykių subjektas, jo intencijos ir veiksmai. R. Garigue ir T. Romet teigia, kad „,visi procesai vyksta globalioje informacinëje erdveje, o ji daro tiesioginę itaką šiems procesams" ${ }^{\text {"14 }}$. Pati įtakingiausia veikẻja šioje erdveje yra žiniasklaida, kuri karinių konfliktų metu ,gali paveikti strategines kryptis bei karinių operacijų apimtį “15, tačiau ne mažiau įtakingos gali būti nevyriausybinès organizacijos, transnacionalinès organizacijos, tarptautinès organizacijos, individai, kitos valstybès ar jų kariuomenès, jei jos sugeba efektyviai kontroliuoti informaciją globalioje informacinèje erdvejje. Praeitame dešimtmetyje šioje erdveje dominavo tokios

\footnotetext{
${ }^{13}$ Garigue R., Romet T., „Information Warfare and the Canadian Forces“, National defense, May 1996. http://www.iwar.org.uk/iwar/resources/canada/iw_\&_cf.pdf 06092003.

${ }^{14}$ Ten pat.

${ }^{15}$ Ten pat.
} 
tarptautinės žiniasklaidos korporacijos, kaip CNN, BBC, tačiau dabar ị šias pozicijas pretenduoja islamo kultūrą ir vertybes propaguojantys Al-Jazeera, Al-Arabia televizijos kanalai. Kokị svarbų vaidmenị televizija vaidina globalioje informacinėje erdvèje, parodo ir J. Chirac iniciatyva steigti prancūziškajį CNN analogą: „Tai teisètas mūsų šalies siekis, ir aš norečiau, kad jis būtų igyvendintas; Prancūzija turi aktyviau dalyvauti filmuotos medžiagos kovoje, kuri vyksta tarp pasaulio televizijų“16.

Šioje globalioje aplinkoje išauga teroristinių, radikalių religinių ar panašių organizacijų reikšmè, o jų veiksmai konflikto metu griauna iki tol vyravusį Clausewitz modelị. John Keegan teigia, kad informacijos amžiuje bus būdingi postmodernūs konfliktai ir valstybè turi būti pasiruošusi juos spręsti: „Postmodernaus karo samprata griauna suvokimą, kad karai vyksta tarp suverenių valstybių, kai smurtu siekiama įtvirtinti vienos valstybės politinę valią prieš kitą" ${ }^{\text {"17 }}$. Nauja konflikto samprata atspindi valstybės suvereniteto, politinès valdžios fragmentacijos tendenciją. Karas nebėra tik valstybiu politika, vykdoma kitomis priemonèmis, - tai gali būti teroristų „politika“. Gerokai mažeja galimybės kontroliuoti konfliktą - anksčiau už tai atsakingos būdavo konflikte dalyvaujančios valstybės. Postmodernus konfliktas nebetenkina ir kitų Clausewitz karo trikampio sampratos teiginių: nebelieka aiškaus skyrimo tarp karių ir civilių, keičiasi ir jų vaidmuo konflikto metu. İ tarptautinius karinius konfliktus įsitraukiant teroristinèms organizacijoms ar radikalioms religinèms grupuotėms, smurto vykdytojai tampa tarsi beasmeniai „tarptautiniai teroristai“. Be to, civilius jie pasirenka kaip „legitimius“ karinius taikinius. Kinta ir šiu grupių vaidmuo konflikto metu. Pirma, konflikte dalyvaujančių pusių politiniai tikslai nebėra tokie aiškūs arba jų neįmanoma kontroliuoti, pavyzdžiui, jei tarptautinių teroristų tikslas yra kova su JAV ir visa Vakarų civilizacija, iškyla klausimas, kaip ir kada šis tikslas bus pasiektas. Antra, konflikto metu Clausewitz civiliams priskyrè materialios ir ideologinės paramos savo valstybei vaidmenį, tačiau informacinè revoliucija pasireiškia globaliu skaidrumu, todèl esmine problema tampa vidaus ir tarptautinės paramos politiniams bei kariniams tikslams garantavimas. Čia galima pateikti ir Lietuvos pavyzdị karo Irake metu, kai mūsų šalies televizijos žiūrovai galëjo stebėti karo veiksmus ne tik per tarptautinius CNN ar BBC televizijos kanalus, bet ir per Al-Jazeera, kurią retransliavo TV3 kanalas $^{18}$.

\section{Valstybès vaidmuo užtikrinant savo piliečių saugumą informaciniame amžiuje}

Taigi naujame tarptautinių santykių ir saugumo kontekste valstybès peržiūri savo pasirengimą dalyvauti naujo tipo kariniuose konfliktuose, analizuoja priemones, kuriomis būtų užtikrinamas savo piliečių saugumas. Andriu Latham mano, kad „šiuo metu vyksta karo reikalų revoliucija, kai industrinį totalų karą (I ir II Pasauli-

${ }^{16} \mathrm{~J}$. Chirac siūlo ịsteigti ištisą parą transliuojantị pasaulinị žinių kanalą. http://www.delfi.lt/archive/ index.php?id=178403306092003.

${ }^{17}$ Mansbach R., Rhodes E., (note 9) p. 59.

${ }^{18}$ TV3 transliuos „Al-Jazeera“ kanalo medžiagą, http://www.delfi.lt/archive/index.php?id=2085167 06092003 . 
niai karai) keičia toks karas, kurị galima pavadinti ịvairiai: informacijos karas, tikslinių smūgių karas, kibernetinis karas ${ }^{19}$. Tokị paradigminị pokytị lemia keletas faktorių: tobulejjanti karo technologija, ypač tai, kas susiję su informacijos revoliucija; naujų technologijų dèka mažejanti masinė armija* ; be to, po Šaltojo karo besiformuojanti nauja, bet grèsmę kelianti saugumo aplinka. Tačiau ne mažiau svarbi yra JAV - šios revoliucijos flagmano - tradicija naujas koncepcijas įtraukti į taktinius, strateginius dokumentus - doktrinas. Todèl tai apima ne tik teorinius apmąstymus apie būsimus konfliktus, bet ir praktinị kariuomenès parengimą dalyvauti juose.

Andriu Latham teigia, kad karo istorija yra paženklinta revoliuciniais pokyčiais: patrankos/parako, Napoleono karų, industrinio totalaus karo ir pan. revoliucijos. Kai kurie autoriai skiria iki dešimties tokių revoliucinių etapų, kiti, kaip Alvin Toffler, šneka apie tris revoliucines karų bangas: ikiindustrinę, industrinę ir informacinę $^{20}$. Dupuy, remdamasis greičio ir technologijos kaitos santykiu, teigia, kad egzistuoja keturi periodai, o rusu generolas ir teoretikas Slipchenko mano, kad Persijos illankos kare buvo naudojami šeštos kartos ginklai ${ }^{21}$. Tačiau svarbiau išsiaiškinti ne tai, kuri periodizacija yra tiksliausia, o tai, kodèl dabartiniai karo reikalų pokyčiai yra laikomi revoliuciniais. Martin Show teigia, kad praeito amžiaus kariniai konfliktai buvo totalūs dèl dviejų priežasčių: pirma, konflikto metu valstybès pagrindini dẻmesį skyrẻ totaliam griovimui; antra, šie konfliktai išsiskyrẻ totalia visuomenès ir valstybès ekonomikos karo reikalų mobilizacija ${ }^{22}$. Pažvelgus ị konfliktus Persijos ilankoje, Kosove, Afganistane ir Irake, i akis krenta tikslinis, o ne totalus griovimo pobūdis. Be to, vidaus ir tarptautinių karo veiksmų palaikymas yra vienas esminių konflikto sẻkmès garantų, o tam reikia didžiulių pastangų - daug didesnių nei totaliu karų metu. Andriu Latham mano ${ }^{23}$, kad karo pokyčius derètų laikyti revoliuciniais dèl trijų priežasčių: informacinè revoliucija pakeitè informacijos surinkimą, saugą, perdavimą ir pristatymą, t. y. šio proceso greitis artẻja prie nulinės ribos, o tai leidžia kalbėti apie virtualų karo lauko vaizdą - suprantama, kad keičiasi sprendimų prièmimo kariuomenejje procesas iš hierarchinio ị decentralizuotesnį. Be to, masini griovimą keičia tikslinis griovimas, o tai sąlygoja masinès armijos mažèjimą, t. y. atsiranda profesionalių, specializuotų pajègų poreikis. Trečioji priežastis - grèsmių diskurso evoliucija, t. y. išnykus JAV ir Sovietų Sajungos priešpriešai atsiranda jau minètos naujos konflikto ašys.

JAV armijos Operacijų ir planavimo Departamentui priklausantis Strateginių Studijų institutas savo tyrime „Karinis konfliktas XXI amžiuje: informacinè revoliucija ir postmodernus karas" teigia, kad kariuomenè šiuo metu turi būti ypač savikritiška ir tuo pat metu ịvertinti pokyčius, vykstančius globaliame versle: „Šiandien

\footnotetext{
${ }^{19}$ Latham A., „Re-imagining Warfare: The „Revolution in Military Affairs“ // Snyder C.A. ed., Contemporary Security and Strategy, New York: Routledge, 1997, p. 210.

" Lietuvos kariuomenès reformos planai taip pat numato nuo 20 tūkst. iki 7 tūkst. mažinti karinị rezervą, taip pat turètu mažėti savanorių skaičius - Lietuvos kariuomené persitvarkys kolektyvinei gynybai, http://www.delfi.lt/archive/index.php?id=186910806092003.

${ }_{20}$ Toffler A., War and anti-war: Survival at the Dawn of the Twenty-first Century, 1993, p. 301.

${ }^{21}$ Bosch J. M. J., „Information Operations: Some Operational Reflections“" in Bosch J. M. J., Luiijf

H. A. M., Mollema A.R., eds., Information Operations, NLARMS, 1999, p. 80.

${ }^{22}$ Latham A., (note 19) p. 216.

${ }^{23}$ Latham A., (note 19) p. 220.
} 
sèkmingai ir efektyviai verslo organizacijai būdingas globalus požiūris ị verslą, decentralizuotą valdymą, strateginès partnerystės tinklą visame pasaulyje bei lankstumą priimant svarbiausius sprendimus" ${ }^{\text {"24 }}$. Atitinkami pokyčiai turètų vykti ir karinèje srityje. Kaip jau minèta, informacijos amžiuje svarbiausias faktorius yra efektyvi informacijos kontrolé, todèl JAV Gynybos departamentas yra įsitikinęs, kad šalies kariuomenè ateities kariniuose konfliktuose turi siekti informacijos dominavimo ${ }^{25}$. Ši nuostata įtvirtinta Vieningoje Informacinių operacijų doktrinoje. Anot J. M. J. Bossch, ,informacinès operacijos lemia ne tik karinę sferą - jos daro poveikį nacionaliniams, tarptautiniams ir globaliems politikos, ekonomikos sluoksniams, taip pat valstybėms, sajungoms bei tarptautinèms visuomenėms ${ }^{\text {“26 }}$ ir jos gali būti naudojamos įvairiose konflikto spektro stadijose.

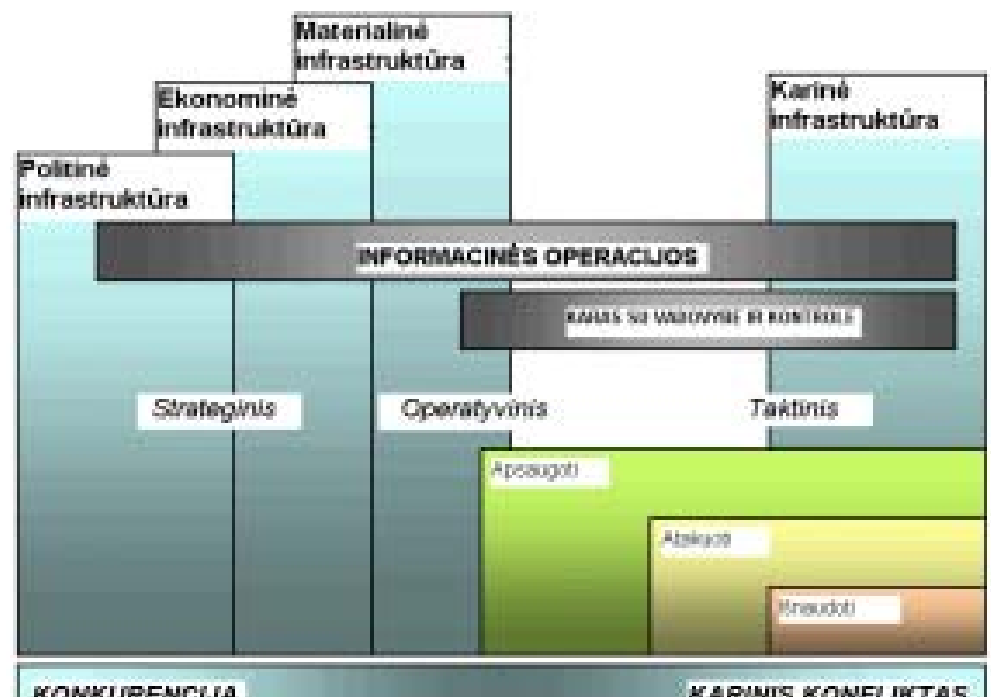

KONKURENCIJA

KARINIS KONFUKTAS

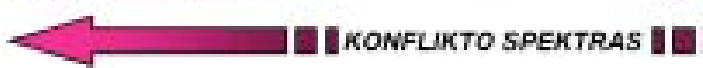

3 schema. Informacinių operacijų vaidmuo konflikto spektre ${ }^{27}$

\footnotetext{
${ }^{24}$ Metz S., Armed Conflict in the 21st Century: the Information Revolution and Post-modern Warfare, Strategic Studies Institute, 2000, p. vii.

${ }^{25}$ Ten pat, p. x.

${ }^{26}$ Bosch J. M. J., (note 21) p. 79.

${ }^{27}$ Information Warfare Architecture, http://www.herolibrary.org/iwarch.htm 06092003.
} 


\section{JAV požiūris ị informacines operacijas}

Informacinių operacijų samprata oficialiuose JAV dokumentuose pirmą kartą atsirado $1992 \mathrm{~m}$. gruodžio mèn., kai Gynybos departamentas patvirtino 36.00.1 direktyvą, kur informacinès operacijos taip apibrèžiamos: „Tai ị globalią informacinę erdvę nukreipti kariniai veiksmai, kuriais siekiama paveikti priešininko informacines arba

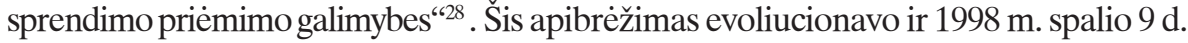
patvirtintoje Vieningoje informacinių operacijų doktrinoje pateikiama paskutinè jo versija: „Informacinés operacijos - tai veiksmai, kuriais siekiama paveikti priešininko informaciją ar informacines sistemas, drauge apsaugant savo informaciją ir informacines sistemas $^{\text {‘29 }}$. Pabrěžtina, kad ir Rusija 2000 m. patvirtintoje karinejje doktrinoje ị informacines operacijas žvelgia taip pat kaip ir JAV: „Informacinès operacijos - informacinès (informacinès techninès bei informacinès psichologinès) atakos, nukreiptos prieš Rusiją ar jos sajungininkes ${ }^{\text {“30 }}$. Tais pačiais metais patvirtinus Rusijos Informacinio saugumo doktriną, buvo siekiama apsaugoti Rusiją nuo potencialių informacinių atakų.

JAV Vieningoje informacinių operacijų doktrinoje pabrěžiama, kad informacinių operacijų naudojimas konflikto metu yra „esminè sąlyga, norint pasiekti iškeltus uždavinius" ${ }^{\text {"31 }}$. Doktrina numato, kad minètos priemonès turi būti taikomos tiek strateginiame, tiek operatyviniame, tiek taktiniame lygiuose, nepriklausomai nuo konflikto intensyvumo: ir karinėse operacijose ne karo metu, ir krizėse, ir pačiame kare $^{32}$. Taigi šie veiksmai apima visą konflikto spektrą, kuris buvo pristatytas 3 schemoje. Dokumentas apima puolamąsias ir gynybines informacines operacijas, jų definicijas, naudojimo organizavimą bei vadovavimą. Be to, dalis dokumento yra skiriama informacinių operacijų planavimo metodologijai, koordinavimo principams, nemažai dėmesio skiriama apmokymams, pratyboms ir modeliavimui. JAV Vieningą informacinių operacijų doktriną derètu laikyti išsamiausiu ir esminiu kariniu dokumentu, skirtu šiai naujai ateities karinių konfliktų sferai.

\section{Vieningų doktrinų hierarchija}

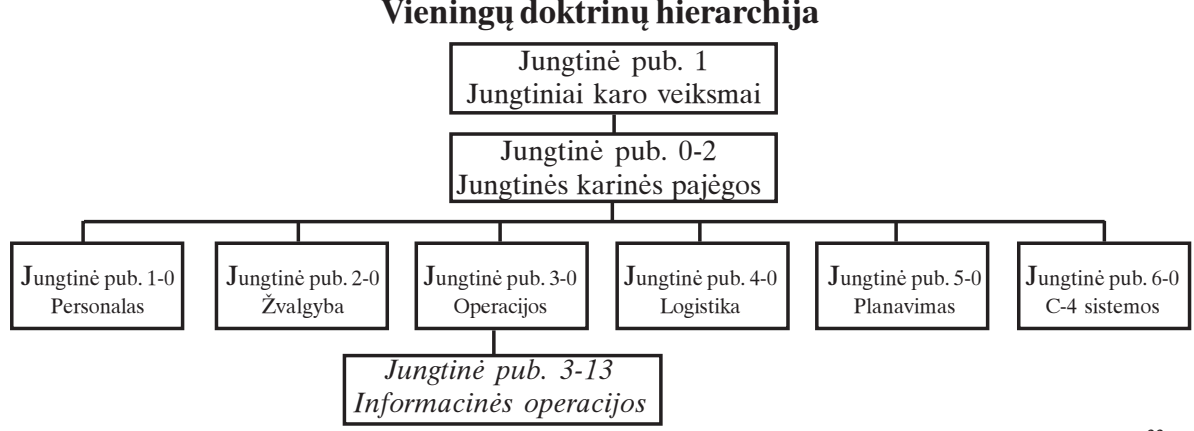

4 schema. Informacinių operacijų doktrinos vieta vieningų JAV doktrinų hierarchijoje ${ }^{33}$

${ }^{28}$ Bosch J. M. J., (note 21) p. 91.

${ }^{29}$ Joint Doctrine for Information Operations, 1998, www.dtic.mil/doctrine/jel/new_pubs/jp3_13.pdf 06092003.

${ }^{30}$ Военная доктрина Российской Федерации. - Совет Безопасности Российской Федерации, 200004 21, http://www.scrf.gov.ru/Documents/Decree/2000/706-1.html 06092003.

${ }^{31}$ Joint Doctrine for Information Operations, (note 28) p. vii.

${ }^{32}$ Ten pat, p. II-7.

${ }^{33}$ Ten pat, p. GL-11. 
Doktrinoje puolamosios informacinès operacijos, t. y. „,veiksmai, kuriais siekiama paveikti priešininko informaciją ar informacines sistemas", apima operatyvinị saugumą, karinị nuslẻpimą, psichologines operacijas, elektroninị karą, fizines atakas - griovimą, specialias informacines operacijas* . Gynybinès informacinès operacijos, t. y. „veiksmai, kuriais siekiama apsaugoti savo informaciją ar informacines sistemas", apima informacijos užtikrinimą, operatyvinị saugumą, fizinị saugumą, kontrnuslëpimą, kontrpropagandą, kontržvalgybą, elektroninị karą ir specialias informacines operacijas.

Doktrinoje vadovavimo informacinèms operacijoms funkcija suteikiama Jungtinès vadovybės pirmininkui, kuris „yra pagrindinis Gynybos sekretoriaus patarejas informacinių operacijų klausimais, tvirtina šių operacijų planus, užtikrina nuolatines informacinių operacijų pratybas ir karinio personalo mokymus “34 . Karo vadai „atsako už tiesioginį informacinių operacijų planavimą, vykdymą ir pratybas" ${ }^{\text {“35 }}$. Karinio konflikto metu informacinių operacijų planavimas ir modeliavimas yra patikimas informacinių operacijų ląstelei. Pabrèžtina, kad doktrina numato ateityje reorganizuoti egzistuojančią vadovavimo ir kontrolès ląstelę ị informacinių operacijų ląstelę ${ }^{36}$. Taigi informacinès operacijos JAV ateityje taps karinès strategijos pagrindu. Jos savyje sujungs vadovavimo ir kontrolés funkcijas.

Strateginiame lygyje doktrina numato, kad „bus imtasi veiksmu, kuriais bandoma paveikti visus priešininko galios elementus (karini, politinį, ekonominị bei informacini ), drauge apsaugant savo ir sajungininkų galios elementus ${ }^{\text {“37 }}$. Operatyviniame lygyje informacinès operacijos naudojamos kariniams kampanijos tikslams pasiekti, o taktiniame jos naudojamos konkretiems, kartais specifiniams taktiniams tikslams igyvendinti ${ }^{38}$. Doktrinoje yra išdèstyti principai, kuriais remiantis turi būti vykdomos informacinès operacijos: pirma, pagrindinis šių operacijų taikinys - priešininko sprendimų priëmimo procesas; antra, informacinių operacijų tikslai turi būti aiškūs ir suderinti su nacionaliniais interesais bei bendrais kariniais tikslais; trečia, puolamosios priemonès turi būti parenkamos pagal priešininko pajègumą bei jo atsako galimybes; ketvirta, iš anksto turi būti nustatyta, ar informacinès operacijos yra centrinès, pagalbinès, ar tik dalinès puolamosios karinès priemonès; penkta, šios operacijos turi būti visiškai integruotos ị visus JAV karinius veiksmus ${ }^{39}$. Atkreiptinas dėmesys ị doktrinos teigini, jog strateginiame lygyje informacinès operacijos turi būti paremtos viešosios informacijos kampanija ir glaudžiu bendradarbiavimu su civilinemis institucijomis bei organizacijomis. Doktrinoje teigiama, - ir tai itin svarbu,--kad informacinių operacijų sėkmę nulems karinès ir civilinès sferos informacinių veiksmų derinimas. JAV už viešają informaciją atsako Valstybės departamentas, kuris šias funkcijas centralizavo panaikinus JAV Informacijos agentūrą. Tai turètų tapti pavyzdžiu Lietuvai, kur, reiktų pripažinti, dažnai atskirų Vyriausybès instituciju ar net ministerijų viešosios informacijos veiksmai yra nesuderinti. Karinio konflikto metu toks nesuderinamumas būtų pragaištingas.

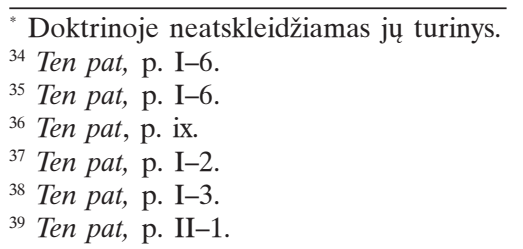


Informacinių operacijų taikiniai gali būti labai ịvairūs: vadovybè (civilinè, karinè, socialinè, kultūrinè ir pan.), civilinė infrastruktūra (telekomunikacijos, transportas, energija, finansai, gamyba ir pan.), karinè infrastruktūra (komunikacijos, žvalgyba, logistika ir pan.), karinès sistemos (lèktuvai, laivai, artilerija, tikslinè ginkluoté, priešlėktuvinė gynyba ir pan.). Visų šių struktūrų efektyvų funkcionavimą užtikrina technika, todẻl ji tampa pagrindiniu taikiniu. Tačiau kadangi technika tėra priemonė tam tikriems veiksmams atlikti, tikruoju taikiniu visada išliks žmogaus protas, o tiksliau-sprendimų prièmimo mechanizmas* .

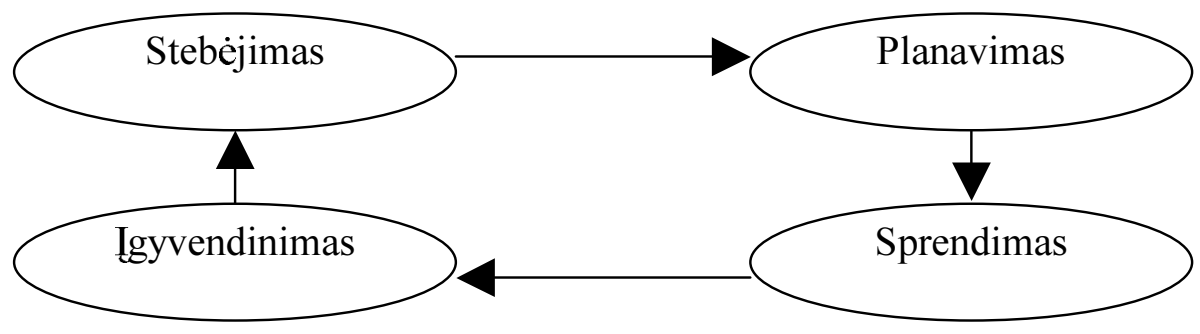

5 schema. Sprendimo prièmimo mechanizmas ${ }^{40}$

Atsižvelgiant į tai, doktrinoje ypatingas dėmesys yra skiriamas informacinių operacijų gynybai: operatyvinio saugumo priemonès turi nustatyti pažeidžiamiausią informaciją ar informacines sistemas ir sukurti jų apsaugos mechanizmus; elektroninio karo priemonės turi prisidèti prie šios apsaugos funkcijos; švietimas ir pratybos turi diegti karinio ir civilinio personalo suvokimą apie informacinị saugumą, nes didžioji informacijos nutekẻjimo dalis - tai žmogiškojo faktoriaus pasekmè; žvalgyba ir kontržvalgyba turi analizuoti ir nustatyti grèsmes; kontrnuslèpimas turi klaidinti priešininką ir nukreipti jo puolamąsias pastangas kita linkme; kontrpropaganda turi atskleisti priešininko psichologines operacijas. Gynyba turètų apimti keturis etapus: informacinès aplinkos apsaugą; atakos šaltinio nustatymą; funkcijų atstatymą ir atsaką i ataką. Doktrinoje informacinè aplinka - tai nacionaliné informacinè infrastruktūra, susidedanti iš privataus, vyriausybès ir gynybos sektorių. Rusijos Valstybinès tarnybos akademijos Nacionalinio saugumo katedros vedèjo pavaduotojas A. V. Vozženikov pabrèžia, kad „vieninga nacionalinè informacinè infrastruktūra bus naudojama kaip efektyvus resursas, tačiau dèl to jis taps potencialiu taikiniu““41 . Tad jos apsauga - tai esminè sąlyga. Be to, apsauga yra ir santykinai pigiausia lyginant su kitų trijų gynybos etapų (atakos šaltinio nustatymo, funkcijų atstatymo, atsako) kaštais. Todèl būtent šioje srityje Lietuva turi perimti jau sukauptą patirtį, ypatingą dèmesį atkreipiant ị mažesnių valstybių, tokių kaip Austrija, pasiekimus, kurie bus aptarti véliau.

* Ši termina įtvirtino JAV Oro pajëgų generolas John Boyd.

${ }^{40}$ US Information Operations Field Manual FM 100-6. - Headquarters Department of the Army, Washington, DC, 27 August 1996, http://www.atsc-army.org/cgi-bin/atdl.dll/query/download/FM/ 100-6/fm100-6.zip 06092003.

${ }^{41}$ Колесникова Е. Что век грядущий нам готовит?, http://www.nosorog.com/public/safety/prognoz.html 06092003. 


\section{NATO požiūris ị informacines operacijas}

Tiek karinėse NATO operacijose, tiek karo strategijos reikaluose JAV visada užèmė lyderio vaidmenį. Todèl nestebina tai, kad NATO požiūris ị informacines operacijas yra beveik identiškas išdèstytam JAV Vieningoje Informacinių operaciju doktrinoje. 1999 m. sausio 22 d. Šiaurés Atlanto Taryba patvirtino NATO informacinių operacijų strategiją. Šis dokumentas nuo JAV doktrinos skiriasi tuo, kad ypatingą dẻmesį sutelkia ị strateginius veiksmus (tai atsispindi pateikiamame informaciniu operacijų apibrěžime): „Strateginiai yra tokie veiksmai, kuriais, siekiant politinių ir karinių tikslų, daroma įtaka sprendimų prièmėjams, paveikiant priešininko informaciją ir informacinius procesus, vadovavimo ir kontrolès galimybes, drauge apsaugant savąsias" “42. Šis apibrèžimas, skirtingai nei JAV suformuluotas, nėra pritaikytas tik karinei sferai. Čia kalbama apie poveikị sprendimo prièmëjams nepriskiriant jų nei kariniams, nei politiniams, nei verslo ar kt. lyderiams, t. y. NATO informacinès operacijos yra orientuotos ị strateginį lygmenị, kur siekiama užsitikrinti paramą savo veiksmams konflikto metu ir tuo pat metu palaužti priešininko valią. Jose Gardeta teigia, kad „strateginiame lygyje informacinemis operacijomis siekiama palaužti visus priešininko galios elementus (politinį, ekonominị, karinị, informacinį) ${ }^{“ 43}$. Todèl NATO informacinių operacijų sampratoje viešoji informacija bei karinių ir civilinių informacinių veiksmų derinimas užima daug svarbesnę vietą nei JAV doktrinoje.

Kaip ir JAV, NATO apibrěžime akcentuojama informacija ir informaciniai procesai, tačiau papildomai išskiriamas vadovavimas ir kontrolè. Karo su vadovybe ir kontrole samprata yra sena kaip ir patys kariniai konfliktai. Priešo kariuomenès vadovybès eliminavimas visada buvo laikomas vienu iš pagrindinių būdų pasiekti pergalę. Kariuomené, netekusi savo vadovybès, būtų ne tik demoralizuota - svarbiausia, ji nesugebètų efektyviai organizuoti ir koordinuoti savo veiksmų. Tačiau informacijos amžiuje nebūtinas fizinis sunaikinimas - užtenka atriboti priešininko vadovybę nuo reikiamos informacijos arba ją iškraipyti, taip atimant iš jos kontrolès galimybę.

NATO taktinèje publikacijoje ATP-3.2 pateikiamas šios organizacijos požiūris tik ị puolamąsias informacines operacijas, nors jų apibrež̌ime akcentuojama ir gynybos nuo šių operacijų reikšmè. Puolamosios informacinès operacijos yra suskirstomos taip: fizinès atakos prieš vadovybę, kontrolę ir komunikacijas, elektroninis karas, operatyvinis saugumas, karinis nuslèpimas ir psichologinès operacijos. Šios priemonès yra analogiškos išdèstytoms JAV doktrinoje, tačiau neįtraukiama specialių informacinių operacijų, už kurias JAV atsako Nacionalinio saugumo agentūra. Tačiau, kaip jau minèta, NATO strategijoje daug didesnis dèmesys nei JAV doktrinoje skiriamas viešosios informacijos ir civilinio bei karinio bendradarbiavimo priemonėms. Viešosios informacijos funkcija - užsitikrinti paramą savo veiksmams konflikto metu. Minètoje taktinejje publikacijoje viešoji informacija yra skirstoma ị karinị ir politinị segmentus. Už karinị viešosios informacijos segmentą atsako

${ }^{42}$ Gardeta J., „Information Operations, the Nato Perspective“ in Bosch J. M. J., Luiijf H. A. M., Mollema A. R., eds., Information Operations, NLARMS, 1999, p. 105.

${ }^{43}$ Ten pat, p. 106. 
NATO vadovybė, kuri siekia „visiškai ir objektyviai, kiek leidžia operatyvinis saugumas, pristatyti ir paaiškinti visuomenei aljanso pasiekimus ${ }^{\text {“44 }}$ ir garantuoti vidaus ir tarptautinę paramą savo veiksmams. Politinis viešosios informacijos segmentas turi būti užtikrinamas koordinuotais visų aljanso narių veiksmais. Jis labiau nukreiptas ị tarptautinės paramos užtikrinimą. Tačiau būtent šiuos veiksmus yra sunkiausia efektyviai igyvendinti dèl didelio valstybių skaičiaus ir dèl to, kad atsakomybẻ už juos tenka įvairioms institucijoms ir organizacijoms (karinèms, politinèms, nevyriausybinèms ir pan.).

NATO informacinių operacijų organizavimas ir planavimas taip pat yra panašus į JAV. Čia egzistuoja informacinių operacijų ląstelès analogas - NATO Informacinių operacijų darbo grupe ${ }^{45}$, kuriai vadovauja Tarptautinio karinio personalo Operatyvinio padalinio direktorius. İ šią darbo grupę įeina karo su vadovybe ir kontrole, psichologinių operacijų ir kiti specialistai.

Nors konflikto metu NATO ypač akcentuojami strateginio lygio veiksmai, operatyvinis ir taktinis lygiai taip pat yra reikšmingi. Jose Gardeta teigia, kad „operatyviniame lygyje informacinès operacijos papildo pagrindines karinès kampanijos priemones ir yra nukreiptos ị priešininko vadovybę ir kontrolę, komunikacijas ir logistiką, o taktiniame lygyje padeda siekti specifinių taktinių uždavinių“46.

NATO taktinejje publikacijoje, kaip ir JAV doktrinoje, yra išdèstyti principai, kuriais remiantis turi būti vykdomos informacinès operacijos ${ }^{47}$ : pirma, karo vado, kuriam tenka visa atsakomybè už informacines operacijas, vadovavimas; antra, visu veiksmų koordinavimas ir integravimas ị bendras karines priemones; trečia, tiksli žvalgybinè informacija, kuri turi būti informacinių operacijų pagrindu; ketvirta, visi veiksmai turi būti nukreipti ị vadinamaji priešininko gravitacijos centrą, t. y. ị jo pažeidžiamiausias vietas; penkta, informacinés operacijos turi remtis centralizuoto planavimo ir decentralizuoto ịgyvendinimo principu; šešta, turi būti aiškiai nustatytas potencialių taikinių sąrašas; septinta, informacinèms operacijoms turi būti ruošiamasi dar prieš prasidedant pačiam kariniam konfliktui, tai ypač taikytina informacinių atakų gynybai; aštunta, vykdant šias priemones turi dominuoti lankstumas ir galimybė prisitaikyti prie vykstančių pokyčių; devinta, turi būti nuolatos įvertinamas panaudotu priemonių efektyvumas.

Jose Gardeta apibendrina NATO požiūrị i informacines operacijas ir teigia, kad ,jomis galima paveikti valstybės šerdị, jos infrastruktūrą, pagrindines egzistavimo funkcijas ${ }^{\text {" } 48}$, todèl informacinès operacijos atlieka savotišką atgrasymo funkciją ir „turẻtų būti naudojamos taikos metu siekiant krizių prevencijos“449. Tačiau tai yra labai sudètingas uždavinys dèl pačios NATO prigimties. Ši organizacija - tai valstybių sajunga, kuri dažnai neranda bendros kalbos dèl kur kas paprastesnių klausimų, nei informacinès operacijos. NATO neturi tokios vieningos valios naudoti puolamą-

\footnotetext{
${ }^{44}$ ATP-3.2 Allied Tactical Publication „Information operations, Psichological Operations and Public Information" p. 3-3.

${ }^{45}$ Gardeta J., (note 40) p. 113.

${ }^{46}$ Ten pat, p. 108.

${ }^{47}$ ATP-3.2 Allied Tactical Publication „Information operations, Psichological Operations and Public Information“ p. 3-2.

${ }^{48}$ Gardeta J., (note 40) p. 105.

${ }^{49}$ Ten pat, p. 105.
} 
sias ar gynybines informacines operacijas, kokią turi JAV. Visu pirma taip yra dẻl to, kad informacinès operacijos yra gana nauja koncepcija NATO karinėje strategijoje. Be to, ji yra sukurta pagal JAV Vieningos Informacinių operacijų doktriną ir neaišku, ar visiškai atitinka šios gynybinès sajungos poreikius. Antra, (ir, matyt, svarbiausia), šią sajungą sudaro daugelis valstybių, kurių požiūris ị atskirų informacinių priemonių naudojimo galimybes skiriasi. Valstybėse įvairiai suvokiamos teisinès pasekmės, todèl skiriasi apribojimai psichologinèms operacijoms, elektroniniam karui, kompiuteriniams įsilaužimams ir pan. Be to, informacinių operacijų sẻkmé didžia dalimi priklauso nuo žvalgybinès informacijos, o NATO šios informacijos turi tik tiek, kiek jos suteikia kiekviena iš valstybių.

\section{Karinis konfliktas informaciniame amžiuje: ko Lietuvai derètụ pasimokyti?}

Lietuva neturi galimybių savarankiškai vystyti tokių informacinių operaciju programų bei strategijų, kokios yra JAV ir NATO, tačiau tai nèra būtina, nes, mūsų šaliai įstojus į Šiaurès Atlanto aljansą, reikès perimti ir šios gynybinès organizacijos karinius standartus, prisitaikyti prie čia egzistuojančių strategijų ir programų, įskaitant ir informacines operacijas. Šiuo metu esminiai yra du faktoriai. Pirma, derètu atsižvelgti ị tai, kad NATO pagrindinị dèmesị skiria strateginèms informacinèms operacijoms, kur svarbiausią vaidmenị vaidina viešoji informacija. Antra, tarp Lietuvos karo, politikos mokslų ekspertų reikia skatinti diskusiją apie besikeičiantị karinio konflikto pobūdį, nes globali informacinè erdve neturi ribų, todèl joje vykstantys konfliktai yra potencialiai grèsmingi ir Lietuvai. Derètų kelti klausimą, kaip tokioje besikeičiančioje saugumo aplinkoje galima efektyviau užtikrinti valstybės piliečių ir tarptautinį saugumą. Todèl ypač svarbu pasirūpinti mūsų valstybės informaciniu saugumu.

\subsection{Suderinta viešosios informacijos strategija - raktas ị sèkmę}

NATO informacinių operacijų programoje viešoji informacija yra laikoma viena iš esminių komponentų ịvairiose konflikto arba krizės stadijose: jos pagalba galima išvengti krizès, atgrasyti priešininką nuo tam tikrų veiksmų, o konfliktui prasidejjus - vidaus ir tarptautinei viešajai nuomonei įrodyti savo veiksmų pagrịstumą. NATO taktinėje publikacijoje viešoji informacija yra taip apibrěžiama: „Tai informacija, kuri paskleidžiama arba publikuojama, siekiant kokybiško visuomenès informavimo ir užsitikrinant supratimą bei palaikymą "50 . JAV informacinių operacijų doktrinoje, kaip ir NATO programoje, viešoji informacija yra skirstoma į informaci-

${ }^{50}$ ATP-3.2 Allied Tactical Publication „Information operations, Psichological Operations and Public Information“, p. 3-25. 
ją, skirtą išorès ir vidaus auditorijoms, tačiau NATO dokumente kaip atskira auditorija yra išskiriamos kareivių giminès ir artimieji bei teigiama, kad „prioritetas visada bus atiduodamas šiai auditorijai“"51 . Tai labai svarbus aspektas, turint omenyje Rusijos pirmają karinę kampaniją Čečenijoje, kai vietinè žiniasklaida ypatingą dėmesi skyrè rusų karių aukoms ir aukų artimiesiems.

Išorinė viešoji informacija yra nukreipta į žiniasklaidą ir, anot NATO dokumento, turètų remtis šiais principais: pasitikèjimas yra pagrindas - niekada negalima meluoti žiniasklaidai; kiekvienas karinės operacijos aspektas gali turèti viešumo pasekmes; informacijos ribojimas darosi praktiškai neįmanomas, todèl turètų būti taikomas tik saugumo sumetimais; negalima teikti prioritetų vienai žiniasklaidos priemonei kitų sąskaita - informacija turi būti prieinama visiems vienodomis sąlygomis; visada reikia stengtis suteikti informaciją; ne visos naujienos yra palankios, bet net ir blogos naujienos turi savo teigiamą pusę (kareivių herojiškumas, pagalbos sužeistiesiems suteikimas ir pan.); žiniasklaida yra pagrindinis informacijos skleidèjas, todèl ji yra reikšminga informacinių operacijų dalis; viešosios informacijos kampanija turi būti vykdoma per visas konflikto fazes; žiniasklaidos susidomèjimas nėra nuolatinis - kartais jị reikia skatinti; NATO pajègos negali būti atribotos nuo viešosios informacijos; žurnalistai turi būti akredituoti prie $\mathrm{NATO}^{52}$. Atkreiptinas dèmesys į tai, kad viešoji informacija apima visą konflikto spektrą: nuo paprastos konkurencijos iki karinès konfrontacijos. NATO programoje numatyta, kad konflikto metu už viešają informaciją atsako Viešosios informacijos karininkas, kuris naudojasi nuolatiniu ir nenutrūkstamu ryšiu su karine vadovybe.

Šiame dokumente, aptariant viešają informaciją, dar kartą akcentuojama globalios informacinès erdvės reikšmė ir daroma esminè išvada, kad informacijos kontrolè ir cenzūra moderniame pasaulyje tapo praktiškai neįmanoma ir gali tik pakenkti politiniams ir kariniams tikslams. Tai įvyko dẻl technologinių pokyčiu , kurių pasekmè - tai karinių ir privačių komunikacijos priemonių atskyrimas ir nepriklausomybè. Ankstesniuose kariniuose konfliktuose, pavyzdžiui, Vietname, žiniasklaidai taip pat buvo teikiamas svarbus vaidmuo, tačiau drauge buvo bandoma kontroliuoti žurnalistų perteikiamą informaciją, nes žurnalistų veikla priklausè nuo to, ar kariuomenè suteikia komunikacijos priemonių reportažams perteikti, ar ne. Atsiradus nešiojamiems kompiuteriams, videotelefonams ir kitoms priemonèms, žurnalistai tapo nepriklausomi nuo kariuomenès technikos. Todèl norèdama efektyviai vykdyti viešosios informacijos kampaniją, NATO turëjo prieiti prie tam tikrų išvadų: pirma, esminis bendravimo su žiniasklaida metodas tapo ,atvirumas žiniasklaidai ir nepriklausomai žurnalistikai“533 , antra,tai nebestebina po karinio konflikto Irake patirties, - žurnalistų įtraukimas ị karinius padalinius siekiant tam tikro emocinio prieraišumo prie karių ir paramos jų vykdomoms užduotims; žiniasklaidos pranešimai negali būti cenzūruojami nepriklausomai nuo to, ar jie perteikiami per privačius, ar per NATO komunikacinius kanalus; informacijos saugumas turi būti užtikrinamas šaltinio, o ne informacijos perteikèjo-žurnalisto lygmenyje. Taigi iš viešosios informacijos strategijos dingo tokie anksčiau svarbūs žodžiai, kaip informacijos kontrolè ir cenzūra.

${ }^{51}$ Ten pat, p. 3-30.

${ }^{52}$ Ten pat, p. 3-30.

${ }^{53}$ Ten pat, p. 3-30. 
Vidaus komunikacija kiekvienoje organizacijoje yra labai svarbi funkcija. Kariuomenèje ji palaiko karių moralę ir ryžtą. NATO vidaus viešosios informacijos priemonès yra vidiniai laikraščiai, žurnalai, biuleteniai, radijas, televizija bei kt. priemonès. Be to, kariams bendrauti su artimaisiais garantuojama saugi ir greita pašto tarnyba, elektroninio pašto priemonès.

Kitas svarbus viešosios informacijos aspektas - tai mokymai ir pratybos visiems NATO kariuomenès atstovams - tiek paprastiems kariams, tiek karininkams. Taktine publikacija numato, kad NATO personalas turi dalyvauti kursuose „Žiniasklaida šiandien“, „Žiniasklaida ir žmogaus teisès“, „Kaip atsakyti į žurnalistų klausimus“, „Saugumas šaltinio lygmenyje“, o personalo vadovai ir karininkai - kursuose „Susitikimo su žurnalistais planavimas“, „Kaip perteikti žinią“, „Interviu principai“, „Brifingai“ ${ }^{“ 54}$.

\subsection{Informacinis saugumas ir Lietuvos pasirengimas}

Nepriklausomai nuo Lietuvos narystės NATO, mūsų šaliai būtina užsitikrinti nacionalinès informacinès infrastruktūros saugumą. Pavyzdžiu galètų būti ir mūsų Rytų kaimynas: 2000 m. rugsėjo 9 d. buvo patvirtinta Rusijos Federacijos informacinio saugumo doktrina, kuri „yra Nacionalinio saugumo koncepcijos tęsinys informacinèje srityje $[\ldots]$, formuoja valstybès politiką informacinio saugumo srityje, $[\ldots]$ rekomenduoja, kaip tobulinti teisinę bazę, $[\ldots]$ skatina kurti tikslines informacinio saugumo programas ${ }^{455}$.

Tačiau Lietuvai tikslingiausia būtų remtis nedidelès Europos valstybès Austrijos požiūriu ị informacinị saugumą. A. A. J. Forstner - Billau, aprašydamas šios valstybès patirtị, teigia, kad nacionalinę informacinę infrastruktūrą sudaro trys tarpusavyje susiję sluoksniai: privati, federacinè (arba vyriausybinè) ir karinè informacinès infrastruktūros. Siekiant efektyvaus saugumo, būtina apsaugoti visas šias infrastruktūras. Karinè infrastruktūra visada būna geriausiai apsaugota, nes remiasi vienodų standartų ir reikalavimų diegimu bei mokymu. Daugelis valstybių panašią politiką bando pritaikyti ir vyriausybinèms informacinèms infrastruktūroms, tuo tarpu daugiausiai problemų kyla dèl privačios infrastruktūros nesaugumo. „Nacionalinė informacinè infrastruktūra, kuri yra modernios visuomenès stuburas, yra neleistinai pažeidžiama nusikaltèlių, teroristų ar priešiškai prieš valstybes nusiteikusių asmenų veiksmų “56 . JAV informacinių operacijų doktrina atskleidè tai, kad didžiosios valstybès investuoja didžiulius finansinius resursus ị šią sritị. Tuo tarpu mažąsias valstybes galima būtų suskirstyti ị tris grupes: Austrijos tipo valstybès, kurios suvokia šią problemą ir bando ją spręsti, kita grupe net nesuvokia šios problemos, o Lietuva ir kitos panašios valstybės šios problemos neakcentuoja, tačiau, kaip paradoksalu bebūtų, kopijuodamos užsienio valstybių patirtị iš dalies ją sprendžia.

\footnotetext{
${ }_{54}^{54}$ Ten pat, p. 3-31.

55 Доктрина информационной безопасности Российской Федерации, http://www.scrf.gov.ru/Documents/Decree/2000/09-09.html 06092003.

${ }^{56}$ Forstner-Billau A. A. J., „Information Operations: Ideas for a Strategic Approach in a Small Country“ in Bosch J. M. J., Luiijf H. A. M., Mollema A. R., eds., Information Operations, NLARMS, 1999, p. 231.
} 
Informacinio saugumo klausimais Lietuvoje susirūpinta, kai, ruošiantis narystei ES, buvo siekiama perimti „Europa“ programos priemones: „Informaciniu technologijų dèka didinti sudaromų sandorių saugumą, pradedant technologiniais sprendimais ir baigiant teisinèmis priemonemis ${ }^{“ 57}$. Be to, 2001 metų lapkričio $23 \mathrm{~d}$. Europos Tarybos iniciatyva Vengrijos parlamente 30 Europos valstybių pasirašė konvenciją dèl kovos su didejjančia elektroninių nusikaltimų grèsme. „Remiantis sutartimi, pasirašiusios valstybès ịsipareigojo steigti nacionalinius nuolat veikiančius centrus, teikiančius savitarpio pagalbą visais su kompiuteriniais nusikaltimais susijusiais klausimais, pradedant kompiuteriniais įsilaužimais ir išeikvojimais ir baigiant grèsmę gyvybei keliančiais sunkiais nusikaltimais" ${ }^{\text {“58 }}$. Tačiau Lietuvoje dėmesys skiriamas tik valstybinei informacinei infrastruktūrai.

JAV informacinių operacijų doktrina karinę informacinę infrastruktūrą laiko geriausiai apsaugota, tačiau dèl to, kad ji yra praktiškai neatsiejama nuo vyriausybinès ir privačios informacinių infrastruktūrų, ji taip pat pažeidžiama. Geriausiai problemą dèl privačios infrastruktūros pažeidžiamumo apibendrina A. A. J. Forstner Billau: „Seniau informacinès technologijos versle buvo diegiamos kaip vienetinès sistemos, kurios praktiškai neturèjo jokių sąryšių su kitomis sistemomis, todèl skyrèsi ne tik pačios technologijos, bet jos buvo ir nesuderinamos - dabar nuosekliai ir nepaliaujamai bandoma spręsti šią problemą “"59 , o informacinių technologijų korporacijos uždirba nemažai pinigų. Dabar besivystantis Rytų Europos valstybių verslas diegia gerokai pažangesnes technologijas, kurios privalo atitikti bendrus, įskaitant ir saugumo, standartus, nes to reikalauja verslo logika. Tačiau A. A. J. Forstner-Billau mano, kad privačios informacinès infrastruktūros apsaugos procesą galima paspartinti: „reikia ị rinką pritraukti geros kokybės informacinès apsaugos produktus, kurie yra brangūs ir dažnai neịperkami vietiniam verslui, todèl mažos valstybės verslas turètų būti patrauklus didžiụjų korporacijų investicijoms, dalis iš kurių būtų skiriama informacijos apsaugai ${ }^{“ 60}$.

Mažų valstybių vyriausybinès informacinès infrastruktūros susiduria su analogiškomis problemomis, kaip ir privatus sektorius. Viešojo administravimo informacinès sistemos kūrèsi taip pat nekontroliuojamos - tai buvo atskirų ministerijų ar agentūrų informacinès sistemos, nederinamos tarpusavyje. Tačiau informacinio saugumo problemos sprendimas viešojo administravimo sektoriuje turi esminị privalumą - čia egzistuoja galimybė patikèti problemos sprendimą konkrečiai institucijai ir pareigūnams, kurie už tai atsakytų. Austrijoje Federacinèje kanceliarijoje buvo įsteigta taryba Informacinių technologijų suderinamumo klausimams spręsti ${ }^{61}$.

2001 metais Lietuvos Respublikos Vyriausybė, kurdama palankias sąlygas saugiai informacinès visuomenès ir elektroninès valdžios plètrai, informacinių technologijų saugos veiksmų koordinavimą valstybiniame sektoriuje pavedė vykdyti Vidaus reikalų ministerijai. Ministerija parengè Informacinių technologijų saugos valstybinę strategiją bei jos iggyvendinimo priemonių planą, siekiantį 2005 metus. Abu šie

\footnotetext{
${ }^{57}$ IT sauga: valstybès institucijų sauga, Informacinès visuomenès pletros komitetas, http://www.ivpk.lt/ main-aktual.php?cat=61\&n=806 092003.

${ }^{58}$ Ten pat.

${ }^{59}$ Forstner-Billau A. A. J., (note 54) p. 231.

${ }^{60}$ Ten pat, p. 233.

${ }^{61}$ Ten pat, p. 234.
} 
dokumentai nustato saugumo užtikrinimo principus, būtinas ịgyvendinti priemones, kurios apima teisinės bazès plètrą, rekomendacijų ir metodikos rengimą, specialistų mokymus, svarbiausių valstybès informacinių sistemų saugos stiprinimą bei visuomenès švietimą ${ }^{62}$. Vidaus reikalų ministerijos Informacinès politikos departamento direktoriaus Aurimo Matulio teigimu, „strategija pabrěžia, kad saugumas turètų būti garantuojamas kompleksiškai, diegiant programines, technines, fizinès saugos ir, žinoma, administracines priemones ${ }^{\text {"633 }}$. Reiktų atkreipti dèmesį, kad strategija pabrèžia informacijos reikšmingumo principą, kuris yra vienas esminių tiek JAV, tiek NATO informacinio saugumo sampratose. Anot A. Matulio, „,saugos priemonės turėtų atitikti resursų, kuriuos siekiama apsaugoti, vertę ir galimus jų pažeidimo padarinius - ne kiekvienai sistemai reikia maksimalios saugos, todėl diegtinos saugos priemonès pasirenkamos atsižvelgiant $i$ jų reikšmę ir būsimas saugos sąnaudas " ${ }^{\text {"64 }}$. Be šio, strategija numato ir kitus principus: aplinkos stebejimo, informacijos technologijų saugos sistemos ir informacinių sistemų tarpusavio priklausomybė, informacijos technologijų naudotojų ir specialistų švietimas ${ }^{65}$. Pastarasis principas yra pabrèžiamas ir JAV informacinių operacijų doktrinoje. Jis ypač svarbus, nes, anot A. Matulio, ,informacinių technologijų saugumas organizacijose didžia dalimi-apie $70 \%$ - priklauso nuo žmogiškojo faktoriaus bei organizacinių procesų ir tik apie 30 procentų - nuo technologinių priemonių “66 .

Minètai strategijai 2002-2004 m. igyvendinti numatyti 3,2 mln. Lt. Be to, siekiant įdiegti saugumo valdymo principus valstybès institucijose Vyriausybė patvirtino Bendruosius duomenų saugos reikalavimus ${ }^{67}$. Jie nustato, kad valstybès institucijos turès parengti ir, suderinusios su Vidaus reikalų ministerija, patvirtinti saugumo politiką bei užtikrinti jos laikymąsi savo veikloje. Reikalavimai buvo suderinti ir su Lietuvos savivaldybių asociacija, todèl jais rekomenduojama vadovautis ir savivaldybėms ${ }^{68}$.

Svarbus ir A. Matulio teiginys, kad „Lietuvai sėkmingai integruojantis į NATO bei Europos Sajungą būtina tinkamai pasirengti kartu saugiai dirbti elektroninèje erdvejje, užtikrinti saugų pasikeitimą informacija tarp mūsų šalies ir tarptautinių organizacijų bei užsienio šalių“69. Todẻl Valstybès saugumo departamentas, Krašto apsaugos ir Vidaus reikalų ministerijos kartu kuria saugumo sistemą, garantuosiančią saugų elektroninių valstybės paslapčiu apdorojimą, saugojimą bei perdavimą kompiuterių tinklais. Šioje srityje atliekamus Lietuvos specialistų darbus gerai ịvertino NATO bei JAV ekspertai ${ }^{70}$.

\footnotetext{
${ }^{62}$ Lietuvos Respublikos Vyriausybès nutarimas Dèl informacijos technologiju saugos valstybinès strategijos ir jos igyvendinimo plano patvirtinimo, $2001 \mathrm{~m}$. gruodžio $22 \mathrm{~d}$. Nr. 1625.

${ }^{63}$ Siekiama užtikrinti informacinių technologijų saugumą Lietuvoje, Vidaus reikalų ministerija http://www.vrm.lt/nuorodos/rvs/sp030108.htm 06092003.

64 Ten pat.

${ }^{65}$ Lietuvos Respublikos Vyriausybès nutarimas Dèl informacijos technologiju saugos valstybinès strategijos ir jos igyvendinimo plano patvirtinimo, $2001 \mathrm{~m}$. gruodžio 22 d. Nr. 1625.

${ }^{66}$ Siekiama užtikrinti informacinių technologijų saugumą Lietuvoje , Vidaus reikalų ministerija http://www.vrm.lt/nuorodos/rvs/sp030108.htm 06092003.

${ }^{67}$ Lietuvos Respublikos Vyriausybès nutarimas Nr. 2105 Dèl duomenu saugos valstybès ir savivaldybiu informacinèse sistemose, $2002 \mathrm{~m}$. gruodžio $31 \mathrm{~d}$.

${ }^{68}$ Siekiama užtikrinti informacinių technologijų saugumą Lietuvoje, Vidaus reikalų ministerija http://www.vrm.lt/nuorodos/rvs/sp030108.htm 06092003.

${ }^{69}$ Ten pat.

${ }^{70}$ Ten pat.
} 


\section{Išvados}

Informacijos amžiuje vyks postmodernūs kariniai konfliktai, kai globalioje informacinèje erdvejje valstybès ir kiti tarptautinių santykių subjektai sieks įtvirtinti savo politiką jëgos priemonèmis. Tačiau šie konfliktai nebebus panašūs ị Clausewitz modelį, kai vadovai iškelia politinius tikslus ir kontroliuoja karius, kariai tiesiogiai kariauja ir yra teisèti smurto taikiniai, o civiliai nedalyvauja konflikte, bet remia savo vadovus mokesčiais bei palaiko jų iškeltus politinius tikslus. Informacijos amžiaus konfliktas - tai ikivestfalinis konfliktas, kai nusikaltimai prieš civilius ir valstybès vidaus tvarką buvo norma. Tačiau konflikte naudojamos priemonės bus pačios moderniausios.

Valstybės turi ieškoti naujų būdų savo piliečių saugumui užtikrinti. JAV bei kitos didžiosios valstybės mano, kad sèkmę ateities konfliktuose gali užtikrinti informacinis dominavimas globalioje informacinėje erdveje, o tai galima pasiekti informacinių operacijų pagalba. Ypatingą reikšmę šių operacijų metu turi viešosios informacijos priemonės bei karinės ir civilinės sferų informacinių veiksmų derinimas. Tokią strategiją yra paruošusi NATO, todẻl Lietuvai reiktų perimti šią patirtị.

Informacijos amžiuje valstybės savo gerovę sieja su informacinès visuomenès, žinių visuomenės, elektroninès vyriausybės ir pan. programomis. Tačiau informacija gali būti ne tik gamybos, bet ir griovimo pagrindas, todèl kiekviena valstybè ypatingą dèmesị turi skirti informaciniam saugumui. Lietuva jau žengè pirmuosius žingsnius šioje srityje: parengtos Informacinių technologijų saugos valstybinè strategija bei jos igyvendinimo priemonių planas iki 2005 metų. Tačiau dar daug ko galima būtų pasimokyti iš Austrijos patirties. 